Producing the docile body: analysing Local Area Under-performance Inspection (LAUI).

Dr Andrew Clapham

University of Nottingham

School of Education

Nottingham

NG8 1BB

Tel: +44 (0)11574 84067

Email: andrew.clapham@nottingham.ac.uk 


\section{Producing the docile body: analysing Local Area Under-performance Inspection (LAUI).}

Andrew Clapham*

School of Education, University of Nottingham, Nottingham, UK

Sir Michael Wilshaw, the head of the Office for Standards in Education (OfSTED), declared a 'new wave' of Local Area Under-performance Inspections (LAUI) of schools 'denying children the standard of education they deserve'. This paper examines how the threat of LAUI played out over three mathematics lessons taught by a teacher in her first year in the profession. A Foucauldian approach is mobilised with regard to disciplinary power and 'docile bodies'. The paper argues that, in the case in point, LAUI was a tool mediating performative conditions and, ultimately, the docile body. The paper will be of concern to policy sociologists, teachers, school leaders, and those interested in school inspection.

Keywords: inspection; docile body; performativity; neo-liberalism; fabrication; post fabrication.

\section{Introduction}

The Office for Standards in Education (OfSTED) is the organisation which inspects educational organisations in England. This paper examines OfSTED's Local Area Under-performance Inspections (LAUI). LAUI was outlined by Her Majesty's Chief Inspector, Sir Michael Wilshaw, and was to be conducted 'within a condensed oneweek period in areas where the proportion of children attending a good or better school is currently well below the national average for England'(Wilshaw, 2013, no page).

\footnotetext{
*Email: andrew.clapham@nottingham.ac.uk
} 
LAUI followed the publication of OfSTED's 2012 Annual Report which found 'marked and unacceptable' variations in school performance between areas with similar demographics and levels of deprivation.

LAUI is investigated through three mathematics lessons taught in an English state secondary school by a key informant in her first year of teaching called, for the purpose of the paper, Keyshaw High and Cheryl Simmons. It is important to stress that this paper explores how Cheryl dealt with the threat of inspection; the paper does not examine her experiences of having an inspector in her room as part of a LAUI. Regardless of LAUI being 'merely' a threat however, the paper suggests that LAUI had major implications for Cheryl's work. LAUI was a different model from 'regular' inspections being a 'no-notice' and only relevant for under-performing schools, requirements which manifested in a particularly high state of readiness being exhibited by the key informant.

The threat of LAUI resonated with what Perryman (2006) calls panoptic performativity where the constant threat of inspection mediates disciplinary mechanisms regardless as to whether schools are physically under inspection or not. This paper proposes that the panoptic performativity inherent in LAUI had a particularly nuanced effect upon the school and teacher in this study and examines the link between LAUI, disciplinary power, and the 'docile body' (Foucault, 1977).

The paper begins by exploring the inspection frameworks in England and how these mediate neo-liberal and performative conditions. Disciplinary power and the production of the docile body are then considered. The design and methodology used in the project are examined and data is presented from the three lessons in question. Links between LAUI and disciplinary power are discussed, and the paper concludes by 
suggesting that in the case in point LAUI, like other disciplinary mechanisms, mediated the production of the docile body.

\section{Inspection framework for English schools}

OfSTED has been in existence since 1984 and was reorganised under the 1992 Education (schools) ACT. The current statutory inspection framework for schools is outlined in sections 5 and 8 of the 2005 Education Act amended in $2012^{1}$. One of the major implications of the 2005 Act was the introduction of 'short notice inspections' where schools were inspected over two or three days with two days, rather than the previous two months, notice. Inspections are categorised as Section 5 scheduled inspections or as Section 8 'monitoring inspections' of schools previously identified to be causing concern (OfSTED, 2012). There are three stages of the current Section 5 inspection process.

Prior to the visit, inspectors examine (a) previous inspection reports (b) parents' responses to online survey (c) possible complaints and (d) the school's website. Reference is made to the school's online data dashboard, sixth form performance and assessment data (PANDA) and Level 3 value added (L3VA) data indicating students' levels of progress. Information regarding governance, staff performance and student behaviour is also analysed (OfSTED, 2014b).

During the visit inspectors observe lessons, examine pupil's work and talk to pupils with a key focus upon literacy and mathematics. Observed lessons are graded in terms of 'key judgements such as achievement and teaching' (OfSTED, 2014b, 12) with feedback offered to teachers after inspection. Pupils are observed at the start and end of

\footnotetext{
${ }^{1}$ The inspection landscape is a changing one (Dean, 2006; Baxter, 2013). During the writing of this paper major amendments were made to the inspection process. In January 2014, OfSTED (2014a) announced 'no notice' inspections of schools where poor student behaviour had been identified and in March 2014 that schools rated as good or outstanding would be inspected over one day, by one inspector, every two years.
} 
school day, during break times, assemblies and tutor periods, and when moving between lessons. Meetings are arranged between inspectors, pupils, parents, governors and other stakeholders.

At the end of the visit, and before the publication of the final report, the lead inspector informs the headteacher of the main findings of the inspection. Schools are ranked as 'outstanding', 'good', 'requires improvement' or 'inadequate' which is the overall effectiveness grade (OfSTED, 2012, 17). This grade is obtained through inspectors examining (a) student achievement (b) quality of teaching (c) pupil behaviour and safety (d) quality of leadership and management.

Schools ranked inadequate can have 'serious weaknesses' or require 'special measures'. Inadequate schools have additional section 8 inspections occurring within a six to eight month window following the last section 5 inspection which can lead to reorganisation of the school or, ultimately, closure (OfSTED, 2012). A school ranked as good is to be inspected within five years of the end of the school year in which its last section 5 inspection took place.

This paper focuses on (a) student achievement, as LAUI focuses specifically on under-achievement, and to a lesser extent (b) pupil behaviour and safety.

OfSTED (2014b) outlines how pupil achievement directly relates to academic achievement. Inspectors focus upon pupils' progress with regard to prior attainment and age with a particular emphasis on the lowest and highest attaining pupils across all year groups. Student achievement is evaluated through observations; scrutiny of work; the school's records of pupil progress; the comparisons of English and Mathematics attainment with national standards and value added indices ${ }^{2}$. A comparison of student

\footnotetext{
${ }^{2}$ Expected progress is defined as three National Curriculum levels of progress between Key Stages 2 and 4.
} 
achievement between schools and national figures is a key indicator of effectiveness (OfSTED, 2014b). The attainment of students who receive the pupil premium ${ }^{3}$ are also significant in the student achievement metric particularly with regard to any differences or 'gaps' in attainment ${ }^{4}$ between this cohort and other pupils in the school.

Student behaviour and safety is inspected through observations, and inspectors accessing school documentation which indicate fixed term exclusions and the number of students taken off role (OfSTED, 2014b). Students are observed during lessons, before and after school and at break times to give inspectors an understanding of pupils' overall behaviour, and levels of safety. Types, rates and patterns of potential bullying are examined, as are the school's efforts to tackle discriminatory and derogatory language.

\section{Inspection, performativity and neo-liberalism}

Inspection is part of the neo-liberal and performative approach to education (Ball, 2007). Performativity has been mobilised as a means of describing changes to the English education system and the conditions in which teachers work (Ball, 2003; Perryman, 2009; Clapham, 2013; Clapham, In Press a; Clapham, In Press b). Performativity engenders universal requirement to produce designated and measurable outcomes, imposed both from within and outside organisations, which frame all activities in those organisations (Lyotard, 1979). Performativity promotes selfregulation though systems based upon performance management, target setting, appraisal and the analysis of school effectiveness outputs (Craft, 2005). Performativity

\footnotetext{
${ }^{3}$ The pupil premium gives schools extra funding to raise the attainment of disadvantaged pupils up to year 11.

${ }^{4}$ Gaps in attainment include the difference between the average point scores in each of English and mathematics in national assessments at the end of Key Stage 2, and at GCSE at the end of Key Stage 4.
} 
research draws on what Lyotard $(1979,27)$ calls the 'legitimation of knowledge'. For Lyotard, performativity is defined by how knowledge is constituted, how knowledge is considered as being of worth, and what knowledge has legitimacy.

The link between performativity and neo-liberalism can be seen, for example, in Lyotard's concept of scientific knowledge and Apple's (2006) work on how the neoliberal market dictates 'what counts' as important knowledge. Performativity is reflected in the increased measurement of performance such as the use of General Certificate in Secondary Education $(\mathrm{GCSE})^{5}$ grades as key indicators of school effectiveness (Nicholl and McLellan, 2008).

In England, performative conditions in state services such as education emerged from the neo-liberal policies of successive UK governments most notably through the work of Sir Keith Joseph, Margaret Thatcher and Tony Blair (Parsons and Welsh, 20006). For Apple (2006), neo-liberalism encompasses traditional liberal principles of right of centre economics coupled with varying degrees of conservative political ideologies. Neo-liberalism is prominent in nations participating in the global economy, although the impact of neo-liberalism extends over a wide geographical area through the activities of groups such as the International Monetary Fund (IMF) and the World Bank (Davies and Bansel, 2007).

Within an educational context, neo-liberalism has positioned schools and education firmly within the competitive market through conservative moderniszation

\footnotetext{
${ }^{5}$ The end of compulsory schooling in England at Year 11 is signified by many students taking
} GCSE examinations. The number of A*-C GCSE grades attained by its students govern the position a school holds in national performance league tables and form part of the data set used by inspectors to rank effectiveness. 
(Apple, 2006) and at the forefront of national, and indeed international, competitiveness (McGregor, 2009). Neo-liberal performative metrics such as Programme for International Student Assessment (PISA) have become significant tools in evaluating the effectiveness of education systems (Shiel and Eivers, 2009).

Inspection, performativity and neo-liberalism are reflected in what Rose calls 'self-government' (1999, p. 264). Self-government reduces the responsibility of the state for the population instead putting the onus on citizens to 'do their bit'. For its proponents, neo-liberalism highlights the rise of the individual and the reduction of regulation. This is however challenged, for example by Ozga $(2009,150)$, who suggests that strategies such as inspection, central to a neo-liberal education agenda, only mediate an appearance of deregulation which is 'equally marked by strong central steering through various policy technologies... (such as inspection frameworks)'.

\section{Disciplinary power and the docile body}

This paper mobilises Foucault's Discipline and Punish: the Birth of the Prison (1977) in which he examines disciplinary power. In disciplinary power there are rules of conduct where individuals are rewarded, or punished, in relation to these rules. Those who are subjected to disciplinary power are also the agents of disciplinary power 'because the constant pressure acts even before the offences, mistakes or crimes have been committed' (Foucault, 1977, 206). Crucially in disciplinary power subjects discipline themselves, with such self-discipline being one of the defining features of technologies such as the Panopticon. Foucault (1977) uses the permanent visibility of the Panopticon prison as a metaphor for disciplinary systems which are applied not only to prisons but also factories, hospitals and schools.

Disciplinary power is not a totalizing system of control centrally held, but circulates through networks of relations between cellular elements. As Ball $(2013,30)$ 
specifies, (disciplinary) 'power is not something that can be possessed'. Disciplinary power, like other modalities such as governmental power, works through subjects and spaces and is not wielded by some against others. As Foucault (1977) indicates, the inspector is also caught up in disciplinary power relations, as they are not simply a privileged arbiter, but as much an inmate of a panopticised system of power as those being inspected.

Concurrent with disciplinary power are 'docile bodies' (Foucault, 1977, 135). For Foucault, a body is docile if it can be 'subjected, used, transformed and improved' (136) with a fundamental link between performance and the docile body. The performing body is rendered docile by the mechanisms of disciplinary power which are used to assess performance such as inspection. Foucault suggests that the docile body is a part of the 'mechanics of power' (138) which consists of (a) enclosure (b) partitioning (c) functional sites (d) rank.

Enclosure is, 'the specification of a place heterogeneous to all others and closed in upon itself' (Foucault, 1977, 141). Welland (2001, 118) suggests that 'discipline proceeds from enclosure' and that enclosure acts to 'inscribe and regulate docile bodies' (117). Enclosure is central to performative surveillance because those who are enclosed are rendered 'visible and vulnerable to the appraisal of others' (128). The notion of enclosure is relevant in a LAUI context due to the heterogeneity, visibility and vulnerability of those schools highlighted as in need of such an inspection. LAUI is both heterogeneous and closed in as it is only relevant to enclosed local authorities and schools identified as under-performing.

Partitioning supplements enclosure in the distribution of disciplinary power. Foucault indicates that the principle of enclosure is 'neither constant, nor indispensable, nor sufficient in disciplinary machinery' $(1977,143)$. For docility to be achieved, the 
precise location of those towards whom the discipline is directed needs to be partitioned. Those schools which fit the criteria for LAUI resonate with Foucault's (143) comments that partitioning is '...to know where and how to locate individuals...to supervise the conduct of each individual, to assess it, to judge it, to calculate its qualities or merits'. LAUI is a tool which partitions schools and teachers as the inspector is aware both the physical location of the local authorities and schools earmarked for LAUI, as well as their location within league tables. LAUI is used to assess, judge and calculate the merits of a partitioned cohort of local authorities and schools.

Functional sites are 'coded spaces' (Foucault, 1977, 143). A coded space can be the physical fabric of a building's architecture, or the metaphorical coding of a space where those within the space are readily observed, analysed and, if necessary, punished. LAUI can be seen as a coded space where individuals are 'distributed in a space in which one might isolate them and map them...' (144). Coded spaces are closely linked to the rank which is 'the place one occupies in a classification' (Foucault, 1977, 145146). Underperforming schools are ranked as in need of, or not in need of, LAUI. The rank engenders docility through aspiration as much as discipline; those of lower rank aspire to a higher one whilst those in a higher rank attempt to maintain their position.

\section{The project}

The research question asked how the threat of LAUI played out in an inner city secondary school by examining three mathematics lessons. Data consisted of field notes (Hammersley and Atkinson, 1995), interviews (Kvale and Brinkman, 2009) and the three lesson observations which followed Delamont's (1976) model. Grounded theory (Glaser and Strauss 1967) was used as the analytical tool where concepts and categories emerged from the data and were coded as indicators of events or actions. The project adhered to the ethical guidelines of the British Educational Research Association 
(BERA, 2011). Informants were approached to give permission for data to be used either prior, or in some case post, data generation and were given the opportunity for their data to be removed from the project.

Reflexivity was an important consideration for this type of qualitative project and acknowledged the researcher's 'past experiences and prior knowledge' (Wellington, 2000, 44). The nature of social research is reflected in the context being explored. Therefore, rather than make 'futile' (Hamersley and Atkinson, 1995, 17) attempts to eliminate researcher effect, the paper acknowledge these effects are in play.

The reflexive process considered the impact of the researcher, and the research, on the key informant in the study. Drawing on the work of Siraj-Blatchford and SirajBlatchford (1997), the researcher's presence in the school, despite not being connected with LAUI, inevitably impacted upon on a teacher who was already under pressure from impending inspection. Acknowledging this impact resonates with the notion of double hermeneutics (Giddens, 1993) where the key informant's actions might have been moderated according to her interpretation of the researcher's understanding of the incidents under investigation.

When considering researcher impact it is important to note that the key informant volunteered to be part of the study, she was under not pressure to participate. She was interested in the inspection process and wanted to contribute to an investigation into a new model of inspection. Having a visitor in her room observing her practice was a normal part of this teacher's day-to-day work and is reflected in some of the data presented in the following sections. She also stressed that the lessons reported here followed what she had planned to do in any event - she reported that the researcher's presence did not lead to her to change her lessons for the visitor's benefit. 
From discussions with the key informant, the researcher's role was one of 'spectator of her world' (McGregor, 2009). The informant was clear that the researcher was not 'one of us', that is, a teacher at the school facing the same performative pressures as her. Nor was the researcher employed by the school in any power position. This enabled the researcher to be spectator in the three lessons and the performative and inspection facing discourses which took place.

\section{Context}

The key informant, Cheryl Simmons, was 23 years old during the project and in her first year of teaching. She always wanted to be a teacher and was delighted to get a post at Keyshaw High. Cheryl wanted to work in a school facing challenging circumstances as she said that this was "where I can make the most difference". She was adamant that she was "in it [teaching] for the long run" and was interested in promotion and leading her own department.

Keyshaw High was a mixed gender 11-18 state school rebuilt in 2012 at a cost of $£ 28 \mathrm{~m}$ and ranked by OfSTED as requiring improvement during its most recent inspection. The majority of the school's pupils were white British (72\%), the largest numbers of minority ethnic background students were of Pakistani $(15 \%)$ and West Indian heritage (11\%). A minority of pupils spoke English as an additional language (3\%) with some at the early stages of English language acquisition (1\%). At 18\%, the proportion of pupils' eligible for free school meals (FSM), an indicator of socioeconomic deprivation, was higher than the national average $(16.3 \%)$.

\section{Mapping assumptions}

Before presenting data from the three lessons, it is important to map some of Cheryl's thoughts on inspection. I interviewed her before lesson 1 and began by asking her if she 
felt schools should be inspected.

Yes! Schools need to be inspected, I want to be inspected as long as it's something that's not just about accountability...it must also be about my development. (Interview)

I asked Cheryl how confident she was as to what was actually required during inspection, be it section 5 or LAUI.

I'm not totally sure...but even people who have been inspected loads of times aren't sure. All the Mockstead stuff is just a rehearsal. My worry is that it [LAUI] won't be anything like what we've been told to expect. I guess this is all new so no one really knows. (Interview)

The unclear requirements of the LAUI, in conjunction with it only being a threat, contributed to Cheryl's "unease" about the process. She stressed that she would feel nervous no matter what type of inspection she was facing. However, the manner of the LAUI announcement which stressed the underperformance element, the unclear criteria as to how LAUI would be conducted, and the potential consequences of a poor inspection report for her school, was particularly unsettling for her.

I asked Cheryl what she considered might be the main LAUI foci.

Good behaviour and good exam grades!!! They're the two main things for the whole school, but for me it's all about the lessons. I have to be able to produce a lesson when the inspectors are in that 'ticks' all the boxes. (Interview)

In the above exert, Cheryl reveals her understanding as to the key requirements for in attaining a good OfSTED report. The notion that good grades and behaviour were fundamental to successful inspection was not only rehearsed by Cheryl as data generated by some students suggest that they also held these assumptions. 


\section{Lesson 1}

Lesson 1 took place shortly after the LAUI announcement in January 2013 and was with 9xy2 who were the second from 'top' set. The lesson explored (a) addition and subtraction of negative numbers (b) evaluation of negative number rules (c) multiplication and division of negative numbers.

Cheryl's first interaction with the class was to explore her desired learning outcomes which were levelled in relation to the KS3 National Curriculum and GCSE examination specification. There was a range of tasks from level 5 to level 7 at $\mathrm{KS}^{6}$ and $\mathrm{C}$ at GCSE. The attainment of the students ranged from level 3.8 to 5.5, predicted levels were between 5.8 to 7.3 . These levels were displayed in the group register and student's exercise books.

It was evident from the start of the lesson that students had an understanding of the importance of these levels, both to them, and to the school:

I sat next to Katie and Kyle. I asked if I could look at Katie's book which she happily handed over. When I went to the page she was currently working at she said "Oh, not there", took the book from me, and gave it back to me with the front cover open and said, "This is where my levels are, I'm predicted a C". (Field note)

Like Katie, most students were happy that they knew their level of work. The majority of students knew their current level as well as the GCSE grade they were predicted to attain in two years time. As I noted at the time:

\footnotetext{
The confidence and security these year 9 kids rehearse in relation to their predicted and actual grades is staggering. The grade they have now is what many of them seem resigned to getting in two years time. It's like they're programmed only to be 'C' grade students! (Field note)
}

\footnotetext{
${ }^{6}$ Level 5 is the national expectation for the end of KS3.
} 
Regardless of the range of tasks available, the majority of students found it hard to maintain focus for sustained periods of time:

The discourses from teacher to students, and from students to student, focussed on "attainment", "examinations", "grades", "tests". When Cheryl did attempt to explore some of the functional aspects of the lesson she was met with poor off task behaviour or comments such as "I'm gonna fail anyway". (Field note)

The parallels displayed in Cheryl's lesson with the work of Thomson et al (2010) are stark. These authors described an 'ongoing aural landscape' (647) which resonated with the frequent discourses surrounding levels and attainment rehearsed by the teacher and students in this lesson as highlighted in the following field note:

The focus was on attainment, and not only for the kids' benefit: it was attainment for the school's benefit in readiness for inspection. (Field note)

Crucial to this lesson was that Cheryl had been instructed by colleagues that the constant reinforcement of students' target grades was an expectation. As Cheryl indicated, she had been told that this was the model "OfSTED wanted" and which we spoke about after the lesson:

This isn't how I want to teach. But the pressure's so great on the school. I don't blame the head because they know that if the inspection isn't good then people will lose their jobs. And I know that a large part of the inspection is about how many Cs we get in maths. (Interview)

The importance of inspection was not lost on the students. As Katie went to leave at the end of the lesson she asked me "are you an OfSTED inspector"7?

\footnotetext{
${ }^{7}$ I was asked questions similar to this by students in all three lessons.
} 


\section{Lesson 2}

Lesson 2 was during the beginning of February 2013 with 10xy1 who were the 'top' mathematics set in year 10. Attainment levels ranged from E to B with the spread of predicted GCSE levels ranging from $\mathrm{B}$ to $\mathrm{A}^{*}$.

The lesson was pitched from the very beginning as being crucial to the students doing well on an 'end of unit' test which they would be completing during their next lesson. The students began with simple powers tasks which then moved into an investigation of fractional powers. The focus was on progressing from the seven 'easy' powers rules to being able to investigate fractional powers. (Field note)

The discourses used both by Cheryl, and the students, were around 'good' levels of attainment. Those that finished early were immediately given an extension task which was described as being a ' $\mathrm{B}$ ', ' $\mathrm{A}$ ' or ' $\mathrm{A}$ *'. Central to the lesson was what constituted a good GCSE grade:

There was a particular emphasis on the C/D borderline students as these were the students Cheryl was told to focus on by a senior teacher as they were "important for OfSTED”. (Field note)

Despite the prominence of the $\mathrm{C}$ grade, Cheryl was relentless in encouraging and supporting all the students, no matter what their present levels of attainment. She was particularly proactive in dispelling the notion some students had that only a $\mathrm{C}$ was a good grade:

So many think that only a $\mathrm{C}$ [and above] is good enough. That must have come from the focus on getting D to C. Who's that for though...it's as much for the inspector as the kids. (Interview)

Cheryl also highlighted the high number of the class [14] who were on 'intervention' strategies designed to ensure they achieved at least a $\mathrm{C}$ at GCSE. These 
students had extra mathematics sessions during the school day which were timetabled in place of other lessons. There were also pre and post school sessions which these students were instructed to attend.

Regardless of these strategies, there was a lack of engagement from a high proportion of the students particularly, those who had already been predicted a $\mathrm{C}$. During the lesson, there were comments such as "What's the point Miss?", "why do I need to know this?", "I've already got a C". There also appeared to be connection between the students' present attainment and their confidence as mathematicians.

...questions such as "How important is this for the exam?" were common. Those who appeared lacking the most in confidence wanted a 'list' of things they needed for the examinations. (Field note)

The need of some students for an exam checklist, and Cheryl's refusal to provide one, seemed to frustrate some of the pupils. Cheryl was determined that the lesson was not 'just about the exam' and rehearsed this with the class. Cheryl's position was that students need to know why an answer was what it was, and it was not enough for them to simply regurgitate answers to examination questions. However, this appeared to cause some students what could only be described as distress. Cheryl's focus on learning through investigation appeared at odds with what some of the students felt was 'teaching'. One student, Storm, was particularly vocal about this. On a number of occasions she spoke to other students loudly enough to be overheard and made comments such as "She's [Cheryl] not teaching me...she won't tell me how to do it". Cheryl chose to ignore this most of the time but she did work one-to-one with Storm on at least three occasions. 


\section{Lesson 3}

Lesson 3 was in early March 2013 with 8xy4 who were the second from bottom set and described as 'challenging' both by Cheryl and Tom, the head of Mathematics. 8xy4's attainment ranged from 4.0-5.1 with the predicted grades at the end of KS3 ranging from 5.2-6.3.

The lesson explored (a) identification of the difference between area and perimeter; (b) identification of patterns and relationships between area and perimeter (c) the area of a compound shape. Cheryl had set up a four station 'carousel' where students spent 10 minutes at each station completing an activity before moving on to the next. For the vast majority of the lesson, students were happily working on the activities. There was a significant amount of group work where the students supported each other on the tasks. There was also a lot of noise, and inevitably materials had been discarded on the floor and desks. However, as I reflected at the time:

There are kids everywhere, stuff on the floor, the room's a mess and I'm getting a headache. But they're learning so much not only about area and perimeter but about working together! (Field note)

The atmosphere in the room was one of excited and engaged learning. As Cheryl told me later:

I love lessons like this. It's about the kids really learning about maths...I only mentioned levelled outcomes at the start because that's school policy. I don't think it's an OfSTED lesson though. (Interview)

After about 30 minutes of the lesson a member of staff entered the room holding a laptop, when I asked Cheryl who this teacher was Cheryl told me she was responsible for 'OfSTED readiness, what Cheryl called 'mockstead' (see also, Clapham, In Press b). Senior staff conducted mock OfSTED inspections where the entire school was 
'inspected' with, for example, an emphasis on marking. Students seemed to be aware of the high stakes nature of such observations. For example, as the teacher conducting the mock inspection left the room I heard a student called Shannon say, whilst pointing at me, "She's [Cheryl] already being inspected". After this incident I made the following note:

This is panopticism in action. Foucault was right...everyone is looking at and inspecting everyone else. Inspection is always going on. (Field note)

Moreover, as the students left the room at the end of the lesson, Mohammed, one of the boys sitting at the back near me said "We were good today, Miss is alright". Mohammed seemed to have a philanthropic attitude toward what he thought was an inspection - because he liked Cheryl he gave what he imagined the inspector wanted to see, 'good' behaviour.

\section{Analysing LAUI}

In this concluding section, I provide possible explanations as to why the threat of LAUI played out in these lessons as it did by returning to the four areas of the docile body.

\section{Enclosure}

Enclosure was achieved primarily through performative discourses and metrics. In lesson 1, Cheryl outlined the relationship between examination scores, inspection, and the threat of teachers losing their jobs. She highlighted how A*-C GCSE grades were fundamental as to whether the school would, or would not, be inspected. Students on the D/C grade GCSE boundary were a prominent focus and enclosed by interventions designed to ensure the achievement of a $\mathrm{C}$.

Both students and teacher accepted the importance of the C GCSE grade as demonstrated by the year 9 students in lesson 1, who confidently rehearsed the GCSE 
grade they were predicted to attain in two years' time. Those who were predicted a C seemed to settle for this despite Cheryl's attempts to motivate them to attain higher. Field notes highlighted that for these students a $\mathrm{C}$ seemed to represent the sum total of schooling and they could not see why they would want more. Those who were predicted less than a $\mathrm{C}$ on the whole wanted to be successful in attaining it but were easily demotivated and distracted.

Cheryl's approach to lessons 1 and 2 was enclosed within an inspection focused lesson model. Cheryl felt that the 'OfSTED lesson' designed to impress an inspection audience was an engrained expectation in the school. She was enclosed by the structures of disciplinary power, mediated by LAUI, which outlined the way she should teach. Cheryl was adamant that lesson 3 was not a lesson she would have taught during an inspection visit, as it did not fit the norm of an OfSTED lesson and therefore was too high risk.

Enclosure was also evident through the conversation with Storm in lesson 2. Cheryl's interaction with Storm, who was perplexed by not being taught, signified how the threat of inspection enclosed this student within a type of lesson. Cheryl's attempt to mediate learning through investigation was met with resistance. Storm was faced with a lesson which did not fit the norm of being 'told the answer', which resulted in her being left worried and confused.

In lesson 3, however, students appeared not to be as overtly enclosed by the conditions of inspection. Of course, it could be argued that there was no way of checking the progress of students against levels and therefore this was an 'unsatisfactory' lesson. However, the lack of discourses around attainment signified an aural landscape of engagement with the tasks rather than levels and grades. 


\section{Partitioning}

Partitioning played out through the discourses of 'good' levels of attainment which ranked Cheryl and her school. Partitioning was mediated by, and required the use of, surveillance both of, and by, the teacher. Cheryl partitioned her students whilst also being partitioned by their attainment. The school was partitioned by OfSTED if attainment data was not at an acceptable level. The school's attainment fed into regional and national data comparisons which partitioned school from school and region from region. Internationally, PISA tables partition country from country.

Partitioning was evident in lessons 1 and 2 through Cheryl's surveillance of behavior and attainment. However, Cheryl was also under surveillance and partitioned through inspection as illustrated by the frequent checks of teachers' book marking, and the aborted 'mockstead' inspection in lesson 3. Partitioning was magnified through this process. Cheryl carried out surveillance of individual students and classes, Cheryl's line manger carried out surveillance of her and so on.

In lessons 1 and 2, Cheryl battled against the expectation by many students that lessons were primarily about the production of assessable materials. However, the partitioning structures were held so strongly by some students that pedagogies not focussing on production were seen as not being pedagogies at all. In the case of the student in lesson 2, she assessed Cheryl's lesson against what she considered to be the norm. A teacher not 'giving' the answer on demand did not fit this norm.

\section{Coded spaces}

The C grade GCSE was the most prominent coded space in Lessons 1 and 2 with students being placed, and placing themselves, within this coded space. However, this positioning within coded spaces did not play out evenly. Those students predicted a C grade appeared happy with their lot and that they had done their job. This did however 
result in a sanguine attitude toward attaining more. Those not attaining the $\mathrm{C}$, despite in most cases wanting to do so, either had to buy into the intervention strategies which were reserved for D/C students or simply resign themselves to not get a 'good' GCSE.

Although less overt than in lessons 1 and 2, lesson 3 also employed coded spaces through the learning outcomes at the start of the lesson which levelled the work in relation to KS3 attainment. However, the nature of the tasks did not readily lend itself to such coding. Part of Cheryl's concern that lesson 3 was not an 'OfSTED' lesson, was the difficulty for the students in self and peer assessing their work. The disparity between explicit coded spaces and the tasks in lesson 3 resulted in Cheryl feeling that this was not a lesson she would attempt during a 'real' inspection.

\section{Rank}

Rank played out in the three lessons in two main ways (a) as a means of delineating academic attainment (b) as a means of delineating inspection attainment. There was crossover between these two instances of rank, as academic attainment fed into inspection attainment. Cheryl's comments in lesson 1, that she did not blame the school for imposing a model of OfSTED friendly lessons, indicated this crossover. For Cheryl, a lesson which would be good in OfSTED terms had to have summative ranking of students attainment as a prominent facet. Without ranking of the students' work the lesson itself could not be ranked as good. Cheryl struggled with this and as a result her use of rank ebbed and flowed with ranking prominent in lesson 1 and 2, less so in lesson 3.

Lesson 1 and 2 had the constant refrain of the rank enacted through the coded space of the C grade GCSE. Lesson 3 had ranking but as a 'bolt on' which reflected its position as a necessary component of 'good' lessons. In lessons 1 and 2, rank mediated forensic investigation into progress and attainment. The aural landscape of rank was not 
solely for the benefit of the students as it was a prerequisite of inspection and as such was rehearsed constantly. Cheryl was both wary of, and resigned toward, the C GCSE coded space being the purpose of her job. She was patently aware that the achievement of the students directly related to the ranking of the school which itself triggered the possibility of LAUI.

\section{LAUI and producing the docile body}

The pattern that emerged from these three lessons was that LAUI resulted in:

- The enclosure of lessons, teachers and students through data

- The partitioning and ranking of lessons, teachers and students though inspection style surveillance and the OfSTED lesson

- The high value given to coded spaces such as the C GCSE grade and the OfSTED lesson

The four areas of the docile body represented in LAUI were constantly redistributed and reassessed during the lessons and could be seen in three key areas - (a) pedagogy (b) the implicit and explicit importance of data, (c) wanting to do well.

(a) Pedagogy - The pedagogy in two of the three lessons followed the model preferred by the school which was designed to produce a 'good' OfSTED lesson. In the third lesson however, the requirements of inspection were not overtly present to the same extent. Nonetheless, inspection was implicit in Cheryl's analysis of the lesson, most notably in her comment that the lesson was not appropriate for an inspection audience. In relation to pedagogy, LAUI produced the docile body through the teacher accepting, in two lessons at least, an 'OfSTED approved' model of teaching.

(b) Data - LAUI was also present in the constant scrutiny of data, primarily in the form of GCSE attainment. Cheryl acknowledged that she inhabited a performative environment, and that there was no escaping the importance of data in this environment. 
Nonetheless, Cheryl rehearsed concerns regarding the school's data culture as the categorisation of students into scores, rankings and targets did not sit well with her (see Blanchard, 2010). In this case, LAUI produced the docile body by making schools, teachers and indeed students' data facing.

(c) Wanting to do well - LAUI produced the docile body through wanting to do well being overtly linked with accepting, and displaying, the assumed requirements necessary for good inspection performance. It was unsurprising that Cheryl wanted to do well as she wanted to well for herself, her school and her students. She did not however want to 'game' (Nicholl and McLellan, 2008) the inspection process to do so. The ways that students wanted to well during LAUI, for example in Lesson 3, revealed a window onto the relationship between teacher and pupil, as well as pupils' assumptions as to what was required for a 'good' inspection.

\section{Conclusions}

This paper argues that the threat of LAUI as a disciplinary mechanism mediated the production of the docile body. This is not to say that the mannerisms of the docile body played out evenly in the three lessons reported here. Sometimes the key informant was docile sometimes not; sometimes she chose to resist sometimes not; sometimes she chose to comply sometimes not.

Cheryl's data revealed shifts in her acceptance of docile conditions. Lesson 3, despite being with her most challenging class, represented the way she wanted to teach mathematics rather than the inspection facing lessons with 9xy2 and 10xy1. Despite these shifts, the pressures upon Cheryl to conform to the successful inspection model were great. Although she produced a "non-OfSTED" lesson in lesson 3, she was clear she would not have been "brave" enough to do so during LAUI. In the case reported here, docility on behalf of teachers and students appeared to be a consequence of the 
threat of LAUI. LAUI brought about an intensification of disciplinary power where Cheryl and her students were enclosed, partitioned, coded and ranked so as to ultimately become docile.

Of course, it could be argued that the role of LAUI in the production of the docile body was not necessarily suggested by the data as these lessons may have been very similar pre LAUI. However, the data does imply that inspection processes, be they section 5 or LAUI, were ingrained in the three lessons regardless as to whether the lessons were different or not post the LAUI announcement. For Cheryl and her students, inspection and the threat of inspection in its various forms were a continuous part of their school lives. The unremitting threat of inspection and with it the presence of panoptic performativity was the power of LAUI as a disciplinary tool. Both teacher and students became responsible for their own observation with the result that the inspector was continually present even when physically absent.

There appeared to be a resigned acceptance by Cheryl and her students of inspection processes such as LAUI. Perhaps this is unsurprising with regard to the students who, in some cases were in their 10th year of formal education, had known nothing other than frequent inspection of their schools and teachers. However, it might have been expected that a teacher, albeit at the start of her career, would want to explore why inspection was so prominent in the education system in which she worked (of course it must also be considered that at 23 , Cheryl was herself a product of a performative neo-liberal education system). During the project there were frequent conversations where the key informant discussed the 'how' of LAUI, but no data was generated around the question asking 'why', and for what purpose, the inspections were taking place. 
From examining the data it appears difficult to be non-critical in accepting the role and purpose of LAUI. The pressures upon a young teacher to conform to the inspection process, albeit only a threat, had a significant impact upon not only her pedagogy but also her professional identity. On one hand, Cheryl acknowledged the high stakes incumbent in the successful negotiation of inspection. On the other, she struggled to reconcile an OfSTED approved approach to teaching with her own beliefs as to what constituted the teacher she wanted to be. Moreover, when considering the efficacy of inspection such as LAUI it has to be acknowledged as to how a negative inspection report, and the effect of this report on a school's position in performance indicator metrics, not only impacts upon the school but also the social geography of the area it serves (Herbert and Thomas, 1998)

The pressure for Cheryl to conform to the expectations of disciplinary mechanisms such as LAUI was considerable. To be able to reproduce the homogenised version of teaching required by LAUI, what DiMaggio and Powell's (1983) call isomorphism, takes a considerable investment of physical, intellectual and emotional capital. Writ large in the data was that fear of the disciplinary consequences incumbent in LAUI drove much of what occurred in two of the three lessons reported here. Allying this fear with the day-to-day challenges which Cheryl Simmons faced, it is perhaps unsurprising that the docile body appears to have been produced.

\section{References}

Apple, M. (2006). Educating the 'right' way. 2nd ed. New York: RoutledgeFalmer

Ball, S. (1997). Good school/bad school: paradox and fabrication. British Journal of the Sociology of Education 18, 317-336

Ball, S. (2003) The teacher's soul and the terrors of performativity Journal of Education Policy 18 (2), 215-228. 
Ball, S. (2007). Education plc: understanding private sector participation in public sector education. Abingdon: Routledge.

Ball, S. (2013). Foucault, power and education. Abingdon: Routledge

Baxter, J. (2013). Professional inspection or inspecting professionals? Teachers as inspectors in a new regulatory regime for education in England. Cambridge Journal of Education, 43, 467-485

British Educational Research Association (BERA). (2011) ethical guidelines for educational research. http://content.yudu.com/Library/A1t9gr/BERAEthicalGuideline/resources/index .htm?referrerUrl=http\%25253A\%25252F\%25252Fwww.yudu.com\%25252Fite m\%25252Fdetails\%25252F375952\%25252FBERA-Ethical-Guidelines-2011

Blanchard, J. (2010). Targets, assessment for learning, and whole-school improvement. Cambridge Journal of Education, 33, 257-271

Clapham, A. (2013) Performativity, fabrication and trust: exploring computer-mediated moderation. Ethnography and Education. 8, no. 3: 371-387

Clapham, A. (In Press a) Post-fabrication and putting on a show: examining the impact of short notice inspections. British Educational Research Journal.

Clapham, A. (In Press b) "Answer your names please": a small scale exploration of teachers technologically mediated 'new lives' Teachers and teaching. Theory and Practice.

Davies, B., \& Bansel, P. (2007) Neoliberalsim and Education. International Journal of Qualitative Studies in Education, 20, 247-259

Dean, J (2006) What teachers and headteachers think of inspection. Cambridge Journal of Education, 25, 45-52 
Delamont, S. (1976). Beyond Flanders fields: The relationship of subject matter and individuality to classroom Style. In M. Stubbs, \& S. Delamont (Eds.), Explorations in classroom observation, (pp, 101-128). London: John Wiley and Sons.

Dimaggio, P., \& Powell, W. (1983). The iron cage revisited: institutional isomorphism and collective rationality in organizational fields, American Sociological Review, 48, 147-160.

Education Act. (2005). (c.18) London: Crown

Foucault, M. (1977). Discipline and punish: the birth of the prison London: Penguin.

Giddens, A. (1993) New Rules of Sociological Method, (2nd ed). Oxford: Blackwell.

Glaser, B., \& A. Strauss. (1967). The discovery of grounded theory: Strategies for qualitative research. Chicago: Aldine.

Hammersley, M., \& Atkinson, P. (1995). Ethnography: Principles in Practice (2nd ed). London: Routledge.

Herbert, D., \& Thomas, C, C. (1998).School performance, league tables and social geography. Applied Geography, 18, 199-223

I. Siraj-Blatchford., \& Siraj-Blatchford, J. (1997). Reflexivity, Social Justice and Educational Research, Cambridge Journal of Education, 27, 235-248

Kvale, S., \& Brinkman, S. (2008). Interviews: Learning the Craft of Qualitative Research (2nd Edition). London: Sage.

Lyotard, J. (1979). The postmodern condition: A report on knowledge (G. Bennington and B. Massumi, Trans.). Manchester: Manchester University Press.

McGregor, M. (2009). Education for (whose) success? Schooling in an age of neoliberalism. British Journal of Sociology of Education 30, 345-358 
Nicholl, B. \& McLellan, R. (2008). 'We're all in this game whether we like it or not to get a number of As to Cs. Design technology teachers' struggles to implement creativity and performativity policies. British Educational Research Journal $34(5), 585-600$

OfSTED. (2012). The framework for school inspection.https://www.education.gov.uk/publications/eOrderingDownload/0900 19.pdf

OfSTED. (2013) A good education for all: inspection of local authority services. Consultation Document. $5 \quad$ February 2013. http://www.ofsted.gov.uk/news/ofsted-launches-consultation-inspection-oflocal-authority-school-improvement-functions

(OfSTED) Office for Standards in Education. (2014a) OfSTED to carry out no notice behaviour inspections in response to concerns of parents. http://www.ofsted.gov.uk/news/ofsted-carry-out-no-notice-behaviourinspections-response-concerns-of-parents-0. Accessed 31 Jan 2014

(OfSTED) Office for Standards in Education. (2014b) School inspection handbook. (OfSTED: Crown)

Ozga, J. 2009. Governing education through data in England: From regulation to self-evaluation. Journal of Education Policy 24, 149-162.

Parsons, C., \& Welsh, P. (2006). Public sector policies and practice, neo-liberal consumerism and freedom of choice in secondary education: a case study of one area in Kent. Cambridge Journal of Education 36, 237-256

Perryman, J. (2006). Panoptic performativity and school inspection regimes: disciplinary mechanisms and life under special measures. Journal of Education Policy 21, 147-161. 
Perryman, J. (2009). Inspection and the fabrication of professional and personal processes. Journal of Education Policy 24, 609-629.

Rose, N. (1999). Governing the Soul: the Shaping of the Private Self (2nd ed.). London: Free Association Books.

Shiel, G. \& Eivers, E. (2009). International comparisons of reading literacy: what can they tell us? Cambridge Journal of Education, 39, 345-360

Thomson, P., Hall, C. \& Jones. K, (2010). Maggie's day: a small-scale analysis of English education policy. Journal of Education Policy 25, 639-656.

Welland, T. (2001). Living in the 'empire of the gaze': time, enclosure and surveillance in a theological college. The Sociological Review 49, 117-135

Wellington, J. (2000). Educational Research: Contemporary Issues and Practical Approaches. London: Continuum.

Wilshaw, M. (2013). Key Note speech to North of England Education Conference. Sheffield, 17 January. http://www.ofsted.gov.uk/news/ofsted-chief-inspector$\underline{\text { announces-measures-tackle-local-area-under-performance-0?news=20203 }}$ 
